I wish to thank the staff of the Agricultural Research Council Radiobiological Laboratory, Let. combe Regis, for allowing the use of the results of early experiments.

Radiobiological Laboratory,

Agricultural Research Council Field Station, Compton, Berkshire.

'Medical Research Council, Committee on Protection against Tonizing Radiations, Brit. Med. J., i, 967 (1959).

2 Squire, H. M., Middleton, I. J., Sansom, B. F., and Coid, C. R., "Radioisotopes in Scientific Research", 4, 207 (Pergamon Press, London, 1958).

${ }^{3}$ Garner, R. J., and Sansom, B. F., Vet. Rec., 71, 670 (1959).

${ }^{4}$ Ilin, D. I., and Moskalev, Y. I., Atomnaya Energiya, 2, No. 2, 163 (1957).

\section{Inability of Methionine to affect Lethality in Mice and Rats exposed to X-Rays}

NerURKar et al. ${ }^{1}$ have shown that administration of methionine either before or after $\mathbf{X}$-irradiation decreases the damage caused to nucleic acid synthesis in irradiated rats. Post-irradiation administration of methionine appears to be more effective. Other assays have shown a lower increase in nitrogen, uric acid and in creatinine excretion in irradiated rats injected with methionine after irradiation ${ }^{2}$. The increase in uric acid excretion suggests excessive breakdown of nucleic acids as a result of cellular destruction. Treatment with methionine also results in a beneficial influence on the rate of growth after irradiation.

The present communication shows that the administration of methionine, apparently effective in slowing down the fall in nucleic acid levels caused by a single exposure to ionizing radiations, affords no decrease in the mortality of mice ( $C 57$ black) and rats (Wistar albino) irradiated with 700 or $800 \mathrm{r}$, of X-rays.

220 male black $C 57$ mice, weighing $20-25$ gm., were divided into eight groups. Each irradiated group consisted of fifteen controls injected intraperitoneally with 0.9 per cent sodium chloride and fifteen animals injected intraperitoneally with an aqueous solution of L-methionine (Sigma) $(5 \mathrm{mgm} ., 25 \mathrm{mgm}$., and $250 \mathrm{mgm}$. $/ \mathrm{kgm}$.) $5 \mathrm{~min}$. before or $30 \mathrm{~min}$. after irradiation respectively. One irradiated group received one

Table 1. EFFECT OF INTRAPERITONEAT INJECTION OF L-METHIONINE BEFORE AND AFTER TOTAL-BODY X-IRRADIATION OF 700 R. OY MORTALITY MOUSE BLACK C57 STRAIN.

kV., 200 ; m.amp., 20 ; d.f., $42 \mathrm{~cm} ., 0.5$ copper ; dosage-rate, 84 r. $/ \mathrm{min}$.

\begin{tabular}{|c|c|c|c|}
\hline Dose of L-methionine & $\begin{array}{c}\text { No. of } \\
\text { animals }\end{array}$ & $\begin{array}{c}\text { Total } \\
\text { mortality } \\
\text { at } 15 \text { days } \\
\text { (per cent) }\end{array}$ & $\begin{array}{l}\text { A verage time of } \\
\text { survival (in days) } \\
\pm S . D .\end{array}$ \\
\hline $\begin{array}{l}\text { Methionine } 5 \mathrm{~min} . \\
\text { before } 700 \mathrm{r} \text {. } \\
\text { Controls } \\
5 \mathrm{mgm} . / \mathrm{kgm} . \\
\text { Controls } \\
25 \mathrm{mgm} . / \mathrm{kgm} . \\
\text { Controls } \\
250 \mathrm{mgm} . / \mathrm{kgm} . \\
\text { Methionine } 30 \mathrm{~min} . \\
\text { after } 700 \mathrm{r} . \\
\text { Controls } \\
5 \mathrm{mgm} . / \mathrm{kgm} . \\
\text { Controls } \\
25 \mathrm{mgm} . / \mathrm{kgm} . \\
\text { Controls } \\
250 \mathrm{mgm} . / \mathrm{kgm} . \\
\text { Chronic treatment } \\
\text { Controls } \\
5 \mathrm{mgm} . / \mathrm{kgm} . \times 11\end{array}$ & $\begin{array}{l}15 \\
15 \\
15 \\
15 \\
15 \\
15 \\
15 \\
15\end{array}$ & $\begin{array}{l}100 \\
100 \\
100 \\
100 \\
100 \\
100 \\
100 \\
100\end{array}$ & $\begin{array}{l}7 \cdot 60( \pm 3 \cdot 34) \\
6 \cdot 80( \pm 1 \cdot 22) \\
8 \cdot 06( \pm 1 \cdot 87) \\
7 \cdot 20( \pm 2 \cdot 78) \\
7 \cdot 60( \pm 2 \cdot 23) \\
8 \cdot 06( \pm 2 \cdot 52) \\
8 \cdot 40( \pm 1 \cdot 88) \\
7 \cdot 13( \pm 1 \cdot 60)\end{array}$ \\
\hline
\end{tabular}

Methionine does not significantly affect the mortality after irradiation $(P<0.01)$
Table 2. EFFECT OF INTRAPERITONEAL INJECTION OF METHIONINE (5 MQM./KGM.) AFTRR A SINGLE TOTAL-BODY X-IRRADIATION OF 800 R. ON MORTality Male Wistak albino Rats. (kV., 200 ; m.amp., 20 ; d.f., 55 em., $0 \cdot 5$ copper ; dose-rate, 50 r./min.

\begin{tabular}{|l|c|c|c|}
\hline Dose of methionine & $\begin{array}{c}\text { No. of } \\
\text { animals }\end{array}$ & $\begin{array}{c}\text { Total mortal- } \\
\text { ity at 30 days } \\
\text { (per cent) }\end{array}$ & $\begin{array}{c}\text { Average time of } \\
\text { survival (in days) } \\
\pm S . D .\end{array}$ \\
\hline $\begin{array}{c}\text { Controls } \\
5 \mathrm{mgm} / \mathrm{kgm} .\end{array}$ & 30 & $96 \cdot 6$ & $8 \cdot 16( \pm 4 \cdot 70)$ \\
\hline 0 & 100 & $8 \cdot 96( \pm 4 \cdot 55)$
\end{tabular}

Methionine does not affect significantly the mortality after irradiation $(P<0 \cdot 01)$

injection $30 \mathrm{~min}$. after irradiation and two daily injections of methionine (5 mgm./ $\mathrm{kgm}$.) during the five days following irradiation. A control group, injected with methionine $(250 \mathrm{mgm} . / \mathrm{kgm}$.), was not irradiated.

Sixty male Wistar rats, weighing $175-225 \mathrm{gm}$. were divided into two groups of thirty animals each. The first group served as control and received an intraperitoneal injection of 0.9 per cent sodium chlor ide; the second group, an injection of L-methionine 30 min. after a total-body X-irradiation of $800 \mathrm{r}$.

Physical factors of irradiation are given in Tables 1 and 2. All the mice irradiated with $700 \mathrm{r}$. and 96 per cent of rats irradiated with $800 \mathrm{r}$. died between the fourth and fifteenth days after irradiation. The same mortality was observed in the groups treated with methionine before or after irradiation (Tables 1 and 2). $\mathrm{L}$-Methionine is not toxic, at the above-mentioned doses, to our mice or rats. In previous investigations, Bacq et al. $^{3}$ have observed that methionine does not protect mice against $\mathrm{X}$-irradiation. The present results confirm these findings.

According to Nerurkar et al.1.4 there is after irradiation a lack of available methionine, and the injection of methionine should help the restoration of the nucleic acid-synthesizing mechanism. But, in our opinion, this effect of methionine is not sufficiently important to affect the mortality.

ZENON M. BACQ

Marie L. Beaumariage

Département de Pathologie générale,

Institut Interuniversitaire des Sciences Nucléaires, Belgique.

' Nerurkar, M. K., Baxi, A. J., Ranadive, N. S., Nerurkar, M. V., and S.hasrabudhe, M. Nature, 180, 193 (1957).

a Yerurkar, M. K., Baxi, A. J., and Sahasrabudhe, M. B., J. Sci. Indust. Res., 18, C, 175 (1957)

${ }^{3}$ Baca. Z. M., and Alexander, P., "Fundamentals of Radiobiology" (Butterworth, London, 1960)" (in the press).

- Sahasrabudhe, M. B., Proc. Second U.N. Internat. Conf. Peaceful Uses Atomic Energy, Geneva, 23, 94 (1958).

\section{Radioactive 7-lodo-6-Deoxytetracycline in Tumour Tissue}

THE observation ${ }^{1},^{2}$ that several of the tetracyclines are localized in various tumour tissues for prolonged periods of time suggested the possible utility of a tetracycline labelled with iodine-131 in the detection of neoplastic disease by the use of external bodyscanning techniques. In a recent communication ${ }^{3}$ from this Laboratory, the preparation of 7-iodo-6deoxytetracycline was described; this was the first report of an iodotetracycline of unequivocal chemical structure. A labelled iodo (131) derivative was prepared by essentially the same method, by the reaction of $\mathrm{N}$-iodosuccinimide ${ }^{4}\left({ }^{131} \mathrm{I}\right)$ and 6 -deoxytetracycline in concentrated sulphuric acid: 